Chi, Tailan. (2012) Venture Capitalists' Decision to Withdraw: The Role of Portfolio Configuration From a Real Options Lens. Strategic Management Journal. Publisher's Official Version: http://papers.ssrn.com/sol3/papers.cfm?abstract_id=2036399

Open Access Version: http://kuscholarworks.ku.edu/dspace/

[This document contains the author's accepted manuscript. For the publisher's version, see the link in the header of this document.]

\title{
VENTURE CAPITALISTS' DECISION TO WITHDRAW: THE ROLE OF PORTOFLIO CONFIGURATION FROM A REAL OPTIONS LENS
}

\author{
By Yong Li and Tailan Chi \\ State University of New York at Buffalo and The University of Kansas \\ Paper citation: \\ Chi, Tailan. (2012) Venture Capitalists' Decision to Withdraw: The Role of Portfolio Configuration \\ From a Real Options Lens. Strategic Management Journal.
}

\section{Keywords:}

venture capital; project withdrawal; real options; uncertainty; portfolio configuration

\begin{abstract}
:
When does a venture capital firm withdraw from an investment project prior to its completion? This study offers a real options view on this decision by examining the contingent effects of portfolio configuration. We explore how project withdrawal can be influenced by two distinct dimensions of portfolio configuration, portfolio focus in a strategic domain and portfolio diversity across multiple domains. The empirical analysis shows that while portfolio focus weakens the negative effect of industry-level uncertainty on a venture capitalist's propensity to withdraw from a project, portfolio diversity strengthens the effect of uncertainty. This study informs current research on the boundary of real options theory and sheds light on the behavior of venture capitalists in financing entrepreneurship.
\end{abstract}


Chi, Tailan. (2012) Venture Capitalists' Decision to Withdraw: The Role of Portfolio Configuration From a Real Options Lens. Strategic Management Journal. Publisher's Official Version: http://papers.ssrn.com/sol3/papers.cfm?abstract_id=2036399

Open Access Version: http://kuscholarworks.ku.edu/dspace/

Running head: A Real Options View on Venture Capital Withdrawal Decisions

VENTURE CAPITALISTS’ DECISION TO WITHDRAW: THE ROLE OF PORTOFLIO CONFIGURATION FROM A REAL OPTIONS LENS

YONG $\mathrm{LI}^{{ }^{*}}$ and TAILAN CHI ${ }^{2}$

${ }^{1}$ School of Management, State University of New York at Buffalo, Amherst, New York, U.S.A.

${ }^{2}$ School of Business, University of Kansas, Lawrence, Kansas, U.S.A.

Keywords: venture capital; project withdrawal; real options; uncertainty; portfolio configuration

*Correspondence to: Yong Li, School of Management, State University of New York at Buffalo, 326K Jacobs Management Center, Amherst, NY 14260 U.S.A. E-mail: YL67@buffalo.edu

When does a venture capital firm withdraw from an investment project prior to its completion? This study offers a real options view on this decision by examining the contingent effects of portfolio configuration. We explore how project withdrawal can be influenced by two distinct dimensions of portfolio configuration, portfolio focus in a strategic domain and portfolio diversity across multiple domains. The empirical analysis shows that while portfolio focus weakens the negative effect of industry-level uncertainty on a venture capitalist's propensity to withdraw from a project, portfolio diversity strengthens the effect of uncertainty. This study informs current research on the boundary of real options theory and sheds light on the behavior of venture capitalists in financing entrepreneurship. Copyright (c) 2013 John Wiley \& Sons, Ltd.

Accepted for publication in Strategic Management Journal, 34, 2013. 
Chi, Tailan. (2012) Venture Capitalists' Decision to Withdraw: The Role of Portfolio Configuration From a Real Options Lens. Strategic Management Journal. Publisher's Official Version: http://papers.ssrn.com/sol3/papers.cfm?abstract_id=2036399 Open Access Version: http://kuscholarworks.ku.edu/dspace/

\section{INTRODUCTION}

Although an investment project can be embedded with both call and put options (Trigeorgis, 1993, 1996), the earlier and better-known real options models of investment decision making are typically concerned with call options (e.g., Brennan and Schwartz, 1985; McDonald and Siegel, 1986). Perhaps for this reason, early applications of real options theory to strategy and entrepreneurship are also focused on call options (e.g., Folta, 1998; Kogut, 1991; McGrath, 1997). The call options embedded in an investment project generally arise from managerial discretion to delay the start or expansion of the project (e.g., Dixit and Pindyck, 1994), whereas the embedded put options generally arise from managerial discretion to withdraw from or downscale the project, particularly when the investment in the project can be staged (Trigeorgis, 1996). While real options theory has emerged as an important guiding tool for strategy and entrepreneurship (Li et al., 2007; Mahoney, 2005), research studies that question the theory’s boundary of applicability suggest that the employment of real options theory as a guide for the adoption of investment projects may be value destroying if decision makers face difficulty in extricating themselves from failing projects due to wrong incentives or behavioral biases. Adner and Levinthal (2004) specifically call for further empirical work to investigate whether firms make project withdrawal decisions in a way that is consistent with real options theory. The current debate on the boundary of real options theory, therefore, makes it imperative to examine whether the behaviors of firms are consistent with the theory's predictions not only in project adoption (i.e., exercise of a call option), but also in project withdrawal (i.e., exercise of a put option).

We take on this challenge by examining how a key prediction of real options theory is moderated by firm strategic factors in the venture capital context. We analyze how the influence 
Chi, Tailan. (2012) Venture Capitalists' Decision to Withdraw: The Role of Portfolio Configuration From a Real Options Lens. Strategic Management Journal. Publisher's Official Version: http://papers.ssrn.com/sol3/papers.cfm?abstract_id=2036399 Open Access Version: http://kuscholarworks.ku.edu/dspace/

of industry-level exogenous uncertainty on a firm's project withdrawal decision depends on the firm’s portfolio configuration. Firms often invest in multiple projects simultaneously. Although uncertainty is a necessary condition that makes an option valuable (Dixit and Pindyck, 1994; Trigeorgis, 1996), portfolio interaction can also affect a project’s option value and the investment and withdrawal decisions (Kulatilaka, 1995; Trigeorgis, 1993; Trigeorgis, 2005). Extant research has shown that portfolio characteristics such as size, scope, and redundancy influence the call option to delay investment in a project (Hurry, Miller, and Bowman, 1992; McGrath and Nerkar, 2004) or the put option to abandon a project (e.g., Anand, Oriani, and Vassolo, 2007; Belderbos and Zou, 2009; Vassolo, Anand, and Folta, 2004).

This study contributes to current real options research by performing a systematic analysis of how the project withdrawal decision is shaped by firms’ portfolio configurations. Since firms often diversify into multiple strategic areas, we explore the effects of two distinct dimensions of portfolio configuration: portfolio focus within a strategic domain and portfolio diversity across multiple domains. Further, our theoretical analysis explicates two key theoretical mechanisms via which portfolio configuration affects the value of the options embedded in a portfolio and, thus, the withdrawal decision: the extent of duplication in functionality among portfolio projects and the degree of correlation in their returns. While correlation makes portfolio projects less effective hedges in bad times, duplication among portfolio projects reduces their realizable values in good times (Girotra, Terwiesch, and Ulrich, 2007; Johnson, 1987; Kulatilaka, 1995; Margrabe, 1978; Stulz, 1982; Trigeorgis, 1993, 2005). Therefore, we propose from a real options lens that portfolio configuration interacts with uncertainty to shape the project withdrawal decision. 
Chi, Tailan. (2012) Venture Capitalists' Decision to Withdraw: The Role of Portfolio Configuration From a Real Options Lens. Strategic Management Journal. Publisher's Official Version: http://papers.ssrn.com/sol3/papers.cfm?abstract_id=2036399 Open Access Version: http://kuscholarworks.ku.edu/dspace/

We conduct our empirical analysis with a large sample of venture capital investments from 1980 to 2009. Our findings suggest that while portfolio focus weakens the negative effect of industry-level uncertainty on the propensity to withdraw from a project, portfolio diversity strengthens the effect of uncertainty. Our analysis provides significant discriminating evidence for real options predictions on the impact of portfolio interaction (Kulatilaka, 1995; Trigeorgis, 1993) and sheds light on the boundary of real options theory (Dixit and Pindyck, 1994, 2000; Folta, 2005).

This study additionally offers insights into the behavior of venture capitalists (VCs) in financing entrepreneurship. ${ }^{1}$ Because venture capital investments are often made under conditions of uncertainty (Amit, Brander, and Zott, 1998; Gompers, 1995; Sahlman, 1990), the VC usually invests in sequential stages to maintain an option to withdraw from a project (Cossin, Leleux, and Saliasi, 2002; Gompers, 1995; Sahlman, 1990; Trigeorgis, 1996). Moreover, the VC typically finances a portfolio of projects simultaneously (Cumming, 2006), and the option value of a project to the VC varies during the investment process as a result of changes in portfolio configuration. Consequently, the VC can exercise the option to withdraw by divesting its equity stake in a portfolio project prior to its completion, even though the entrepreneur (and possibly other investors) may choose to continue the project. Withdrawal, thus, differs from 'exit,' which usually indicates the end outcome or the natural conclusion of a project, be it a success (e.g.,

\footnotetext{
${ }^{1}$ Venture capital provides a unique context where we can examine how a VC adjusts its decision over time based on updated information at each round of financing, which is the focal concern of dynamic real options theory (Bowman and Hurry, 1993; Trigeorgis, 1996). Many investment projects of strategic importance, such as R\&D, are undertaken in discrete stages, but such staged financing is usually unobservable to researchers. In addition, a study of venture capital withdrawal is important in its own right because of venture capital's important role in financing entrepreneurship. Many of the high tech icons, such as Microsoft, Apple, Cisco Systems, and Genentech, have been venture backed in their early stages. Research studies and industry reports suggest that venture capital has contributed substantially to job creation, innovation, and economic growth in the United States (Global Insight, 2007; Kortum and Lerner, 2000).
} 
Chi, Tailan. (2012) Venture Capitalists' Decision to Withdraw: The Role of Portfolio Configuration From a Real Options Lens. Strategic Management Journal. Publisher's Official Version: http://papers.ssrn.com/sol3/papers.cfm?abstract_id=2036399 Open Access Version: http://kuscholarworks.ku.edu/dspace/

venture IPO or M\&A) (Brander, Amit, and Antweiler, 2002; Gompers and Lerner, 2000) or failure (e.g., venture bankruptcy) (Gimeno et al., 1997; Hochberg, Ljungqvist, and Lu, 2007).

This option to withdraw, a put option, is an important policy tool for the VC making a sequential investment under uncertainty (Bowman and Hurry, 1993; Trigeorgis, 1996). Despite the prevalence and importance of portfolio investments (Cumming, 2006), extant research has yet to empirically examine the effect of portfolio configuration on venture capital project withdrawal. Scholars have been urged to apply real options theory to address important strategic portfolio problems, such as in the venture capital context (Li et al., 2007; Trigeorgis, 2005). Our study fills this research gap by analyzing how portfolio configuration influences venture capital withdrawal under uncertainty. A better understanding of VCs’ project withdrawal behavior has important implications for both academic research on and managerial practice in innovation and entrepreneurship.

The remainder of the article proceeds as follows: the next section presents our theory and derives hypotheses. We then explain the sample and empirical methods. The ensuing section reports the empirical results. The article concludes with a discussion of the implications of the study for research and practice.

\section{THEORY AND HYPOTHESES}

Strategic investments (e.g., R\&D) that are necessary for creating and sustaining competitive advantage are usually undertaken under conditions of environmental uncertainty (Folta and O'Brien, 2004; Trigeorgis, 1996; Vassolo et al., 2004). A firm can invest in sequential stages to hold an option to withdraw from a project prior to its completion (Chi and Nystrom, 1995). Keeping this option alive allows the firm to capitalize on the upside potential of the project, while exercising this option enables the firm to limit downside risks (Bowman and Hurry, 1993; 
Chi, Tailan. (2012) Venture Capitalists' Decision to Withdraw: The Role of Portfolio Configuration From a Real Options Lens. Strategic Management Journal. Publisher's Official Version: http://papers.ssrn.com/sol3/papers.cfm?abstract_id=2036399 Open Access Version: http://kuscholarworks.ku.edu/dspace/

Trigeorgis, 1996). The firm can also invest in multiple projects simultaneously to form an options bundle or portfolio (Bowman and Hurry, 1993; Vassolo et al., 2004) so that the firm enhances its flexibility to withdraw from a particular portfolio project or to gain from growth opportunities (Trigeorgis, 1996). We discuss the classical real options prediction on project withdrawal and then develop the arguments for the effect of portfolio configuration.

\section{Uncertainty and project withdrawal}

Uncertainty plays a central role in the exit and withdrawal decisions according to classical real options theory (Dixit, 1989; O'Brien and Folta, 2009; Trigeorgis, 1996). Specifically, the presence of industry-level exogenous uncertainty means that there is an upside potential as well as a downside risk associated with the project. Since management can adapt to changing environmental conditions, holding open the option to withdraw allows management to exploit the upside potential in the industry when future conditions turn favorable but to keep the downside risk in check when future conditions turn adverse (Kumar, 2005; Moel and Tufano, 2002; O'Brien and Folta, 2009; Vassolo et al., 2004). Consequently, the intervention of withdrawal alters the distribution of gains and losses into a favorably asymmetric shape (Trigeorgis, 1988; 1993). This asymmetric effect of uncertainty on the upside potential and downside risk raises the value of the option embedded in the project, which can be viewed as an opportunity cost of withdrawing from the project now-exercising the withdrawal option kills the opportunity to exploit the upside potential in the industry. Thus, we present the following hypothesis as a starting point of our analysis:

Baseline hypothesis: The higher the level of uncertainty in a venture capital project's industry, the lower the propensity to withdraw from the project, other things being equal. 
Chi, Tailan. (2012) Venture Capitalists' Decision to Withdraw: The Role of Portfolio Configuration From a Real Options Lens. Strategic Management Journal. Publisher's Official Version: http://papers.ssrn.com/sol3/papers.cfm?abstract_id=2036399 Open Access Version: http://kuscholarworks.ku.edu/dspace/

\section{Portfolio configuration and project withdrawal}

Firms usually invest in multiple projects simultaneously to capitalize on the upside potential in an industry and contain downside losses (e.g., Belderbos and Zou, 2007; McGrath and Nerkar, 2004; Vassolo et al., 2004). It is very likely that some of the portfolio projects are partially duplicative in functionality. For instance, two projects on different bioengineered drugs may both work on drug delivery vehicles, and an effective vehicle discovered in one of the projects can cause the other to realize less than its full potential. Moreover, the returns on the evolving projects are unlikely to be perfectly correlated due to differences in the factors that drive their respective returns. The extent of duplication in functionality among portfolio projects and the degree of correlation in their returns are two key theoretical mechanisms affecting the value of the options embedded in a portfolio (Girotra et al., 2007; Johnson, 1987; Kulatilaka, 1995; Margrabe, 1978; Stulz, 1982; Trigeorgis, 1993; Trigeorgis, 2005).

These two theoretical mechanisms for the interaction of options embedded in a portfolio of different projects are related to the basic factors that affect the joint value of multiple interlinked options embedded in a single project (for a seminal study, see Trigeorgis, 1993). First, when two options are embedded in a single asset or two related assets, the options will interact such that the exercise of one option in general alters the value of the underlying asset for the other option. So, the first basic factor that affects the joint value of multiple options is how the exercise of one option affects the value of another. In the context of options embedded in a portfolio of two or more projects, functional duplication between any pair of the portfolio projects can cause adoption of one project to lessen the potential option value of the other project. Second, when two options are embedded in the same asset (but can be exercised only at different points in time) or in two related assets, the circumstances that trigger their exercise (i.e., in the 
Chi, Tailan. (2012) Venture Capitalists' Decision to Withdraw: The Role of Portfolio Configuration From a Real Options Lens. Strategic Management Journal. Publisher's Official Version: http://papers.ssrn.com/sol3/papers.cfm?abstract_id=2036399 Open Access Version: http://kuscholarworks.ku.edu/dspace/

money) are, in general, correlated. A high positive correlation means that the other option is also likely exercisable when the first option is exercisable, while a high negative correlation means that the other option is likely not exercisable when the first option is exercisable. So, a second basic factor that affects the joint value of multiple options is the correlation between the circumstances affecting the exercises of the different options. In the context of options embedded in a portfolio of two or more projects, the pairwise correlation between the returns on the assets determines the likelihood of the embedded options being both exercisable or both nonexercisable. High positive correlations make the portfolio projects poor hedges against risk because the options embedded in such projects are likely to be all 'out of money' in a bad state of nature. Along this line of reasoning, we posit that the configuration of a firm's portfolio of different projects embodies both the extent of functional duplication among the projects and the degree of correlation in their returns, affecting the incremental option value of a portfolio project and ultimately influencing the decision to withdraw from the project under uncertainty.

A firm can vary the configuration of its project portfolio both within an industry and across multiple industries. Portfolio focus is defined as the dispersion of the firm's investment across projects in the same industry, reflecting the level of redundancy that each project on expectation adds to the firm's portfolio of investment projects. The firm's portfolio focus in an industry increases when the firm finances an increasing number of similar or related projects in the industry. Portfolio diversity is defined as the dispersion of the firm's investment projects among different industries, reflecting the degree of spread of the firm's portfolio across industries. The firm's portfolio diversity increases when the firm spreads its investment across an increasing number of industries. Portfolio focus and portfolio diversity are two distinct, but not orthogonal, dimensions of portfolio configuration. For example, a VC can have high portfolio 
Chi, Tailan. (2012) Venture Capitalists' Decision to Withdraw: The Role of Portfolio Configuration From a Real Options Lens. Strategic Management Journal. Publisher's Official Version: http://papers.ssrn.com/sol3/papers.cfm?abstract_id=2036399 Open Access Version: http://kuscholarworks.ku.edu/dspace/

focus in each industry in which it invests and maintain high portfolio diversity across a large number of industries.

When the firm has high portfolio focus in the industry of a focal project, the firm will likely have more projects that are partly duplicative of the functions that the focal project is intended to achieve. In the absence of synergy effects, duplication depresses the joint value of the projects in good times because the duplicative parts of two projects cannot yield more than the value derived from the duplicated part of either, even when both projects are successful (Girotra et al., 2007). In addition, projects in the same industry are likely to experience more industrywide common shocks that cause the returns on these projects to be more positively correlated (Guiso and Parigi, 1999) which, in turn, makes them poorer hedges for one another and reduces the joint option value of the portfolio. It should be noted that, given the impact of industry common shocks on returns, projects that fall in the same industry tend to exhibit higher (rather than lower) positive correlation in their returns regardless of whether the projects are overall substitutes or complements (Girotra et al., 2007; Guiso and Parigi, 1999; Shleifer and Vishny, 1992).

We expect that high portfolio focus will likely attenuate the positive effect of uncertainty on the incremental option value of projects in the industry. High uncertainty makes it beneficial to hold alive the option to withdraw embedded in each portfolio project in the industry, because the option allows the firm to abandon the project and contain downside loss in bad times and to keep the opportunity to exploit the upside potential in the industry in good times (Trigeorgis, 1996). However, since duplication tends to dampen portfolio returns in good times and industry common shocks make the projects less effective hedges against downside risks in bad times, the need for keeping each individual project to tackle or take advantage of uncertainty in the industry 
Chi, Tailan. (2012) Venture Capitalists' Decision to Withdraw: The Role of Portfolio Configuration From a Real Options Lens. Strategic Management Journal. Publisher's Official Version: http://papers.ssrn.com/sol3/papers.cfm?abstract_id=2036399 Open Access Version: http://kuscholarworks.ku.edu/dspace/

is reduced when the firm has high portfolio focus. The firm will be able to keep its options open under uncertainty even if it exercises the option to withdraw from a particular project in the industry given other similar projects being active. The option value of the project prior to its withdrawal derives primarily from the opportunity to exploit the upside potential in the future (Dixit, 1992), and the firm can exploit other similar projects to take advantage of future growth opportunities in the industry. Meanwhile, given high portfolio focus, withdrawing from a particular project will not likely impair the firm's ability to hedge against downside risks in the industry. Consequently, the option value of the project will increase less with an increase in industry-level uncertainty when the firm has a higher level of portfolio focus in the industry. Because the option value of the project raises the opportunity cost of withdrawal, an expected negative interaction effect of portfolio focus and uncertainty on the incremental option value of a portfolio project leads to the following hypothesis:

Hypothesis 1: The higher the venture capitalist's portfolio focus in a project's industry, the weaker the negative effect of uncertainty on the propensity to withdraw from the project.

As compared to portfolio focus, portfolio diversity reflects the dispersion of a firm's investment projects across different industries and has opposite implications for project withdrawal under uncertainty. Projects that fall in different industries are less likely to be duplicative. In addition, projects in different industries tend to face different supply and demand conditions, so their values are less susceptible to industry common shocks. Thus, as a firm’s portfolio diversity increases, the focal project is likely to be less positively correlated in returns with the rest of portfolio projects. Moreover, a low correlation among the returns of the projects tends to increase the relative volatility (spread) of potential outcomes and, thus, enhance the option value (of exchanging one project for another) embedded in the portfolio (Trigeorgis, 
2005). For these reasons, portfolio diversity is less (more) likely to reduce (raise) the incremental option value of projects in an industry.

We further expect that high portfolio diversity will likely accentuate the positive effect of uncertainty on the incremental option value of projects in a particular industry. Under high industry-level uncertainty, the firm is better off keeping open the option to withdraw embedded in a project. As the firm's portfolio diversity increases, the projects will be distributed across a larger number of industries and their returns will be less positively correlated. Consequently, the need for keeping alive a project in a particular industry to tackle or take advantage of uncertainty and exploit the upside potential in that industry increases. In an extreme case where the firm invests in a large number of industries with one project in each industry, a small increase in uncertainty in a particular industry will increase the incremental option value of the project in that industry substantially. Therefore, as the firm has a higher level of portfolio diversity across industries, the return on a given project in the firm's portfolio is, on average, less positively correlated with the return on the rest of the portfolio than is the case with a portfolio focus strategy, so that the incremental option value of each project is, on average, more sensitive to changes in industry-level uncertainty. ${ }^{2}$ Because a higher incremental option value implies a higher opportunity cost of withdrawing from a project, we expect the firm's high portfolio diversity to augment the effect of uncertainty on the propensity to withdraw from the project. Hence:

Hypothesis 2: The higher the venture capitalist's portfolio diversity, the stronger the negative effect of uncertainty on the propensity to withdraw from the project.

\footnotetext{
2 This should be interpreted with some caution. As more and more projects are added across various industries, beyond some point, positive correlation may rise.
} 
Chi, Tailan. (2012) Venture Capitalists' Decision to Withdraw: The Role of Portfolio Configuration From a Real Options Lens. Strategic Management Journal. Publisher's Official Version: http://papers.ssrn.com/sol3/papers.cfm?abstract_id=2036399 Open Access Version: http://kuscholarworks.ku.edu/dspace/

\section{EMPIRICAL DESIGN}

\section{Data and sample}

We collect data on standard venture capital investments in the U.S. from the VentureXpert database. We build the sample on each round of financing by a VC in a venture. We track each VC’s investment in the focal venture from the first financing round across all rounds to the date of VC withdrawal, an exit event, or June 30, 2009, whichever is sooner.

We code a VC's investment in a venture as withdrawn if the VC does not invest in any of the subsequent rounds. We assume that withdrawal occurs at the earliest round date when the VC no longer appears as an investor in the venture in the database. If a VC has invested in the venture until an exit event (such as venture IPO, acquisition, or bankruptcy), the exit is not considered a withdrawal and is censored. If no exit event has occurred by June 30, 2009, but the VC has not invested in the venture since the last reported round, we assume that the VC has withdrawn if 549 days have passed since the last reported round. We use 549 days because a round is followed by a subsequent round or withdrawal within 549 days for 75 percent of the investments in our sample. Our results are robust to choice of other cut-off points, e.g., for 50 or 90 percent of the investments in our sample. We limit our sample to ventures founded since 1970 and receiving initial funding from 1980 to 2001. A venture capital fund typically has a 10-year lifespan with about a seven-year active investment period (Fenn, Liang, and Prowse, 1997; Hochberg et al., 2007; National Venture Capital Association, 2008). Therefore, limiting the initial financing year to 2001 leaves us with at least seven and a half years to observe a possible subsequent investment or an exit event until June 30, 2009 for a venture financed by a VC as late as in 2001. This way, we not only incorporate investments that have long durations between two 
Chi, Tailan. (2012) Venture Capitalists' Decision to Withdraw: The Role of Portfolio Configuration From a Real Options Lens. Strategic Management Journal. Publisher's Official Version: http://papers.ssrn.com/sol3/papers.cfm?abstract_id=2036399 Open Access Version: http://kuscholarworks.ku.edu/dspace/

consecutive rounds of financing (e.g., more than three years), but also reduce any potential nonreport bias of the VentureXpert database. ${ }^{3}$

The final data set includes 52,891 unique rounds (i.e., VC-venture pairs) of venture capital investment by 3,344 VCs in 14,323 ventures, after we exclude observations with missing values. Altogether, 2,924 VCs and 8,877 ventures have been involved in a total of 28,230 withdrawal events; that is, more than 87 percent of VCs in the sample have withdrawn from at least one investment project and about 62 percent of ventures have experienced withdrawal by at least one VC prior to any exit event.

\section{Model specification}

We estimate the propensity to withdraw using the semiparametric Cox survival model because it does not require specifying a particular probability distribution of time dependence of the hazard (Cameron and Trivedi, 2005). We obtain consistent results when using the parametric Weibull model. Our analysis is at the VC-venture-round level. Each VC-venture-round combination is a spell and the data set is divided into 139,042 spells. We use the Huber-White sandwich estimator of variance, clustered on VC-venture pairs, to yield robust standard errors.

\footnotetext{
${ }^{3}$ It is possible that a VC stops investing in subsequent rounds but retains its (diluted) equity in the venture, a case that we call discontinuation of investment without withdrawal or simply discontinuation. VentureXpert does not differentiate between discontinuation and withdrawal, which is a limitation of our empirical analysis. However, the possibility of discontinuation biases our analysis against finding the hypothesized effect of portfolio configuration. First, real options theory suggests that higher uncertainty favors discontinuation (i.e., wait and see) over further investment. Inclusion of the discontinuation cases would, thus, weaken our predictions concerning the negative effect of uncertainty on the propensity to withdraw. Second, we expect portfolio diversity to disfavor and portfolio focus to favor discontinuation over further investment. However, given that uncertainty theoretically should favor discontinuation vis-àvis further investment, portfolio diversity and uncertainty would weaken each other's effect while portfolio focus and uncertainty would strengthen each other's effect on the propensity to withdraw. The interaction effects predicted by our hypotheses would become weaker because discontinuation no longer implies the loss of the project in the VC's portfolio. For these reasons, the possible existence of cases in which a VC does not divest or forfeit its stake after discontinuing investment makes our empirical tests more conservative.
} 


\section{Measures}

Detailed descriptions of the dependent and explanatory variables are presented in Table 1. Our dependent variable is the propensity to withdraw, which is the hazard that a VC withdraws its investment in a venture in the current round conditional on the fact that the VC has invested in the previous round.

Insert Table 1 here

\section{Uncertainty}

Unlike the case for a contingent security, we do not have ready measures for the uncertainty that affects the propensity to withdraw in the venture capital context. It is also unlikely that VCs possess clear valuation signals to guide their investment and withdrawal decisions given incomplete and imperfect information about their portfolio companies. Extant research studies have suggested that VCs respond to public market shifts in their investment decisions (Gompers et al., 2008) and shown that returns of venture capital funds are correlated with the returns on the public market (Cochrane, 2005; Kaplan and Schoar, 2005). Thus, we expect publicly available information to be useful for VCs looking for valuation signals in making their continuation or withdrawal decisions. Accordingly, we focus on sources of industry-level uncertainty that can be attributed to shifts in the public market (e.g., Folta, Johnson, and O'Brien, 2006; Li and Mahoney, 2011). Based on the Venture Economics Industry Classification in VentureXpert, we reclassify an industry as one of the 49 industries defined by Fama and French (1993) (see http://mba.tuck.dartmouth.edu/pages/faculty/ken.french/). The 49-industry classification focuses on shared technological and managerial principles among businesses. Our sample has 
observations for 42 industries (industry distribution data available upon request). Table 1 details how uncertainty is measured.

\section{Portfolio focus and portfolio diversity}

We follow the corporate diversification literature (Jacquemin and Berry, 1979; Palepu, 1985) and construct entropy-type measures for a VC's portfolio focus in a given industry and portfolio diversity across industries.

\section{Control variables}

We include a number of variables to account for the influence of venture-level characteristics. The economic performance of the investment project will likely influence the withdrawal decision. Because the ventures in our sample are private firms, we do not have data about the value of the underlying venture assets or the return of investment projects. Absent tangible economic performance measures, we employ two proxy measures: the venture's stage of development and the growth potential in the venture's industry. The stage of development is an important signal of the venture's commercial potential and the project buildup value at the time of investment. A venture that is at a later stage of development must have passed more stringent evaluation hurdles, have a greater buildup value, and need less further investment to complete. In addition, firms invest in high volatility opportunities that also have high growth potential (McGrath, 1999). While venture-level data are unavailable for predicting growth potential, prior research suggests that public market shifts provide important environmental cues for returns of venture capital projects (Cochrane, 2005; Kaplan and Schoar, 2005). It is reasonable to expect that the VC will keep its withdrawal option open when a market cue signals an unexpected rise in valuation relative to the forecast. Thus, we account for venture industry growth in our estimation (Kogut, 1991). 
Chi, Tailan. (2012) Venture Capitalists' Decision to Withdraw: The Role of Portfolio Configuration From a Real Options Lens. Strategic Management Journal. Publisher's Official Version: http://papers.ssrn.com/sol3/papers.cfm?abstract_id=2036399 Open Access Version: http://kuscholarworks.ku.edu/dspace/

We include three VC-related control variables. First, a large number of coinvestors (VC syndicate size) may put organizational and political pressures on the VC to stay in the project (Guler, 2007). Second, because of the limited life span of many funds, VCs with older funds that are closer to maturity (VC fund age) will likely have a higher propensity to withdraw. Third, VCs that have accumulated experience and expertise in funding riskier earlier stage ventures (VC's early-stage investment experience) may have more patience and lower propensity to withdraw.

We include several dyadic-level controls. First, geographic proximity with the venture helps the VC gather information, reduce monitoring costs, and provide value-added support (Sorenson and Stuart, 2001), which will likely decrease the propensity to withdraw. Second, prior research (e.g., Benson and Ziedonis, 2010) suggests that more rounds of financing by a corporate investor in a venture (Rounds) is associated with a lower likelihood of subsequent refinancing by the corporate investor. Finally, the VC's cumulative disbursement in a venture (VC's total investment in venture) indicates the VC's expected buildup value of the venture and will likely reduce the propensity to withdraw.

We include two market-level control variables. First, IPO market conditions can affect ventures’ abilities to go public as well as venture capital investment practices (Cumming, Fleming, and Schwienbacher, 2005; Gulati and Higgins, 2003; Ritter, 1984). Second, VCs obtain more committed capital in good times. With more capital available (Capital committed to venture capital industry), VCs can choose to continue supporting existing portfolio companies or withdraw from some investments to seek other more promising opportunities.

For all the estimations, we include venture industry dummies and year dummies to control for unobserved interindustry variance and account for unobservable time-varying effects. 


\section{RESULTS}

Table 2 presents descriptive statistics for the variables. The variance inflation factors (VIFs) are less than two for all the variables, and the mean VIF is 1.27. None of the correlations are sources of concern for multicollinearity.

Insert Table 2 here

Table 3 reports the estimation results. Model 1 includes the control variables only. Model 2 tests the baseline hypothesis about the effect of uncertainty. Models 3 and 4 test the hypotheses about the effects of portfolio configuration. Model 5 is the full model and is used to gauge the economic effects of our explanatory variables.

We start with the classical real options prediction, which has not been tested on venture capital withdrawal before. The real options view is that given management's ability to adapt, the VC can take advantage of uncertain industry conditions by holding the option to withdraw, because this option allows the VC to capture the upside potential of a portfolio project while limiting its downside risks. Thus, our baseline hypothesis suggests that uncertainty in a project's industry has a negative effect on the propensity to withdraw from the project, ceteris paribus. Model 2 in Table 3 shows that the uncertainty measure has a negative and statistically significant coefficient estimate, indicating that the VC is less likely to stop refinancing the venture under higher uncertainty. Based on point estimates in Model 5 of Table 3, holding the value of all other variables at the mean level, when uncertainty increases from its median to 80th percentile, the propensity to withdraw decreases by 0.111 , indicating that under high uncertainty, investments will be withdrawn at a rate about 11.1 percent lower throughout the study period than at the 
median level of uncertainty. This is the baseline case. This result offers support for the central prediction of classical real options theory (Dixit and Pindyck, 1994; O'Brien and Folta, 2009; Trigeorgis, 1996; Vassolo et al., 2004) and provides initial evidence for its applicability in the venture capital context.

Insert Table 3 here

All the model estimations in Table 3 show that portfolio focus has a positive, significant coefficient and that portfolio diversity has a negative, significant coefficient. Thus, while portfolio focus increases a VC's propensity to withdraw from a venture project, portfolio diversity has an opposite effect, other things being equal. Holding all other variables, including uncertainty in Model 5, at the mean level, when portfolio focus increases from the median to 80th percentile, the propensity to withdraw increases modestly, by 2.2 percent; a similar increase in portfolio diversity leads to a decrease in the withdrawal hazard by 3.7 percent. We turn to the main hypotheses next.

Insert Figure1 here

Hypothesis 1 holds that the firm's portfolio focus in an industry weakens the negative effect of uncertainty on the propensity to withdraw from a project in that industry. In Model 3, the interaction term between uncertainty and portfolio focus is positive and significant. This result is consistent with Hypothesis 1 . When portfolio focus increases from the median to $80^{\text {th }}$ 
Chi, Tailan. (2012) Venture Capitalists' Decision to Withdraw: The Role of Portfolio Configuration From a Real Options Lens. Strategic Management Journal. Publisher's Official Version: http://papers.ssrn.com/sol3/papers.cfm?abstract_id=2036399 Open Access Version: http://kuscholarworks.ku.edu/dspace/

percentile, the interaction effect for a similar increase in uncertainty, as shown in Figure 1a, is a sizeable increase of 9.4 percent in the propensity to withdraw relative to the baseline case.

Hypothesis 2 indicates that the firm's portfolio diversity strengthens the negative effect of uncertainty in an industry on the propensity to withdraw from a project in that industry. Model 4 shows that the interaction term between uncertainty and portfolio diversity has a negative and significant coefficient estimate, providing support for Hypothesis 2. When portfolio diversity increases from the median to 80th percentile, the interaction effect for a similar increase in uncertainty, as shown in Figure 1b, is a further decrease of 9.9 percent in the withdrawal hazard relative to the baseline case.

Several results for the control variables are noteworthy. First, our findings suggest that VCs make their continuation and withdrawal decisions based on economic analyses of costs and opportunities (Gompers et al., 2008; Li, 2008). For example, VCs seem to hold on to projects that display great upside potential, as indicated by promising commercial potential (stage of development) or favorable industry conditions (venture industry growth). Second, when the venture receives financing from a larger syndicate (syndicate size), the VC's propensity to withdraw from the venture is higher. This result suggests that a large number of coinvestors do not constrain a VC's discretion to deviate and withdraw. Third, VC fund age is positively associated with the propensity to withdraw. Fourth, ventures are less likely to experience withdrawal from VCs that are located closer to them (Geographic proximity). Fifth, VCs are less likely to withdraw from projects to which they have already disbursed larger total amounts of investment (VC's total investment in venture). Finally, consistent with prior research in the corporate venture capital context (Benson and Ziedonis, 2010), when a VC has provided more 
Chi, Tailan. (2012) Venture Capitalists' Decision to Withdraw: The Role of Portfolio Configuration From a Real Options Lens. Strategic Management Journal. Publisher's Official Version: http://papers.ssrn.com/sol3/papers.cfm?abstract_id=2036399 Open Access Version: http://kuscholarworks.ku.edu/dspace/

rounds of financing to a project, the propensity to withdraw from that project becomes higher, other things being equal.

\section{DISCUSSION}

This study presented an analysis of how portfolio configuration influences a firm's propensity to withdraw from a project under uncertainty. Extant research has suggested that the decision to exit and withdraw is influenced by the conditions of uncertainty and irreversibility (Moel and Tufano, 2002; O'Brien and Folta, 2009) as well as the correlation and redundancy among portfolio projects (Belderbos and Zou, 2009; Vassolo et al., 2004). ${ }^{4}$ Our study advances the previous real options work by analyzing the direct and interaction effects of two distinct dimensions of portfolio configuration. We suggest that since many firms invest in multiple strategic areas, it is important to explore the impact of both portfolio focus within a strategic domain and portfolio diversity across multiple domains.

Our theoretical development on the effects of portfolio configuration is in line with the basic principles of option interaction originally exposited in the study on multiple sequential options embedded in a single project (e.g., Trigeorgis, 1993). In the case of options embedded in a portfolio of different but related projects, our analysis further explicated two key mechanisms through which portfolio interaction affects the value of the options embedded in the portfolio: while higher correlation in returns due to industry common shocks makes portfolio projects less effective hedges in bad times, functional duplication among portfolio projects reduces their realizable values in good times. This line of reasoning suggests an inherent interactive effect of

\footnotetext{
${ }^{4}$ For example, Vassolo et al. (2004) suggest that high correlation and redundancy (e.g., high technological overlap) between a firm's portfolio of alliances increases the likelihood of alliance divestiture in a strategic domain (i.e., the biotech industry). In the international context, Belderbos and Zou (2007) show that the likelihood of a multinational firm divesting an affiliate under conditions of macroeconomic uncertainty depends on the redundancy of the affiliate in the host country as well as in the multinational network.
} 
Chi, Tailan. (2012) Venture Capitalists' Decision to Withdraw: The Role of Portfolio Configuration From a Real Options Lens. Strategic Management Journal. Publisher's Official Version: http://papers.ssrn.com/sol3/papers.cfm?abstract_id=2036399 Open Access Version: http://kuscholarworks.ku.edu/dspace/

uncertainty and portfolio configuration on project withdrawal. Limited empirical research has examined how portfolio interactions influence investment and divestiture decisions from a real options perspective (Belderbos and Zou, 2009; Vassolo et al., 2004). Our study is distinct in its focus on the contingent effects of these two dimensions of portfolio configuration.

The current study sheds light on the boundary of real options theory in strategy and entrepreneurship. Given the concern about real options theory’s applicability (Adner and Levinthal, 2004), we tested and found corroborative evidence for the classical real options prediction that uncertainty reduces a firm's propensity to exercise an option (i.e., to withdraw from a project) (see also, Folta et al., 2006). More important, we showed that the impact of uncertainty on the propensity to withdraw depends further on the firm's portfolio focus in an industry and portfolio diversity across industries. This more nuanced approach to analyzing the contingent role of portfolio configuration in project withdrawal provides important discriminating evidence for real options predictions (Dixit and Pindyck, 1994, 2000; Folta, 2005; Trigeorgis, 1993). Overall, our empirical findings affirm the value added of the real options approach in strategy and entrepreneurship (see also Li and Mahoney, 2011; Vassolo et al., 2004). This study has interesting implications for venture capital research and practice. ${ }^{5}$ Our analysis is the first of its kind to address the impact of uncertainty and portfolio configuration on project withdrawal in the venture capital context. Uncertainty is a hallmark of financing entrepreneurship (Amit et al., 1998; Cochrane, 2005; Gompers, 1995; Gompers and Lerner, 2002; Sahlman, 1990). The conventional wisdom from modern portfolio theory (Brealey and Myers, 2000; Markowitz, 1959) is that risk and uncertainty is undesirable and must be minimized (for a given expected return). In practice, it is not surprising to see a VC decide not to finance or refinance a venture because of perceived high uncertainty (Baeyens, Vanacker, and Manigart,

\footnotetext{
${ }^{5}$ We thank an anonymous reviewer for the insights on this discussion point.
} 
Chi, Tailan. (2012) Venture Capitalists' Decision to Withdraw: The Role of Portfolio Configuration From a Real Options Lens. Strategic Management Journal. Publisher's Official Version: http://papers.ssrn.com/sol3/papers.cfm?abstract_id=2036399 Open Access Version: http://kuscholarworks.ku.edu/dspace/

2006). This perspective on risk and uncertainty, however, is inadequate and may lead to an underinvestment bias in financing entrepreneurship (Dixit and Pindyck, 1994; Trigeorgis, 1996). The real options view offers the insight that uncertainty can increase the value of real options or managerial flexibility. Thus, uncertainty is not necessarily something to be avoided or be penalized for, but rather can be seen as a window of opportunity for the more flexible investors to create more value by leveraging their opportunity sets while limiting losses (Trigeorgis, 2005). In the venture capital context, as our baseline hypothesis suggests, the VC can benefit from uncertain industry conditions if it holds open the option to withdraw from a project in that industry. With this option, the VC has an opportunity to seize the growth potential of the project if industry conditions turn favorable in the future but limit its downside losses if industry conditions turn adverse.

This wait-and-see strategy will not always work to the advantage of the VC, however, since the impact of uncertainty is further contingent on the VC's portfolio configuration. Our empirical evidence shows that portfolio focus weakens the negative effect of uncertainty on the propensity to withdraw. Still, portfolio diversity strengthens the negative effect of uncertainty. In this regard, the conventional view is that, as compared with industry specialization that allows VCs to fully utilize their expertise and enhance their value-added services to entrepreneurial companies (Barry, 1994; Norton and Tenenbaum, 1993), industry diversification is primarily intended to reduce risk (Gompers and Lerner, 2002; Knill, 2009; Sahlman, 1990). In comparison, the real options view suggests that since a firm can proactively manage its portfolio projects by adapting to changing environmental conditions, the firm can also use industry diversification to increase the relative spread of outcomes under uncertainty and enhance the value of the options embedded in its portfolio of projects (Trigeorgis, 1996, 2005). The current study, thus, suggests a 
more balanced view on portfolio diversification and indicates that firms need to consider both dimensions of portfolio configuration in hedging uncertainty and exploring growth opportunities in highly uncertain contexts such as venture capital.

\section{Limitations and future research}

Our study can be extended in several areas. First, we have focused on publicly observable sources of uncertainty facing a project that are attributable to industry conditions. There are also venture-specific sources of uncertainty that may not be publicly observable. Although some of our control variables may reflect firm-specific or venture-specific endogenous uncertainty (e.g., rounds) and have effects consistent with real options theory, these measures are indirect and the results are subject to alternative interpretations. Some research has shown that industry-wide uncertainty has a stronger effect on investment decisions than firm-specific uncertainty (e.g., Henley, Carruth, and Dickerson, 2003). In future empirical research, scholars may systematically compare the effects of venture-specific uncertainty and industry-wide uncertainty in venture capital investment and withdrawal decisions, provided that more precise data can be collected on venture-specific uncertainty.

Second, in addition to uncertainty related to market conditions, technological uncertainty can also have an impact on the value of real options (McGrath and MacMillan, 2000; Oriani and Sobrero, 2008). Researchers may examine whether technological uncertainty interacts with portfolio configurations differently (Anand et al., 2007) and has different effects on investment and withdrawal decisions.

Third, our study found a significant effect of portfolio configuration on the VC withdrawal decision. Some follow-up questions include why VCs vary in their portfolio configuration and how such heterogeneity influences VCs’ investment performance. Future 
research along these lines can further our understanding of the behavior and performance of VCs in financing entrepreneurship.

\section{CONCLUSION}

We have shown that real options theory offers important insights into the project withdrawal decision and VC portfolio configuration decisions. Our study tests the theory's applicability by examining how the effects of uncertainty are contingent on portfolio configuration. Further, our analysis shows how we can gain a better understanding of the role of portfolio configuration by analyzing the interaction of uncertainty with portfolio focus within a strategic domain and with portfolio diversity across multiple domains. Finally, our study sheds further light on VCs’ decision making in financing entrepreneurship. We hope this study will encourage further tests of real options theory as an important theoretical tool for strategy and entrepreneurship (Li et al., 2007; Mahoney, 2005; Reuer and Tong, 2007; Trigeorgis, 1996).

\section{ACKNOWLEDGEMENTS}

We are grateful to Coeditor Richard Bettis for his thoughtful guidance and to the anonymous referees for their insightful comments and suggestions in the article’s review process. We thank Douglas Cumming, Tim Folta, Glenn Hoetker, Akie Iriyama, Jing Li, Ravi Madhavan, Joe Mahoney, Jon O’Brien, Raffaele Oriani, Jeff Reuer, Tony Tong, Roberto Vassolo, and Ilan Vertinsky for their valuable comments. The usual disclaimer applies. 
Chi, Tailan. (2012) Venture Capitalists' Decision to Withdraw: The Role of Portfolio Configuration From a Real Options Lens. Strategic Management Journal. Publisher's Official Version: http://papers.ssrn.com/sol3/papers.cfm?abstract_id=2036399

\section{REFERENCES}

Adner R, Levinthal DA. 2004. What is not a real option: considering boundaries for the application of real options to business strategy. Academy of Management Review 29(1): 74-85.

Amit R, Brander J, Zott C. 1998. Why do venture capital firms exist? Theory and Canadian evidence. Journal of Business Venturing 13(6): 441-466.

Anand J, Oriani R, Vassolo RS. 2007. Managing a portfolio of real options. Advances in Strategic Management 24: 285-313.

Baeyens K, Vanacker T, Manigart S. 2006. Venture capitalists' selection process: the case of biotechnology proposals. International Journal of Technology Management 34(1/2): 2846.

Barry CB. 1994. New directions in research on venture capital finance. Financial Management 23(3): 3-15.

Belderbos R, Zou JL. 2007. On the growth of foreign affiliates: multinational plant networks, joint ventures, and flexibility. Journal of International Business Studies 38(7): 1095-1112.

Belderbos R, Zou JL. 2009. Real options and foreign affiliate divestments: a portfolio perspective. Journal of International Business Studies 40(4): 600-620.

Benson D, Ziedonis RH. 2010. Corporate venture capital and the returns to acquiring portfolio companies. Journal of Financial Economics 98(3): 478-499.

Bowman EH, Hurry D. 1993. Strategy through the option lens: an integrated view of resource investments and the incremental-choice process. Academy of Management Review 18(4): 760-782.

Brander JA, Amit R, Antweiler W. 2002. Venture-capital syndication: improved venture selection vs. the value-added hypothesis. Journal of Economics \& Management Strategy 11(3): 423-452.

Brav A, Gompers PA. 1997. Myth or reality? The long-run underperformance of initial public offerings: evidence from venture and nonventure capital-backed companies. Journal of Finance 52(5): 1791-1821.

Brealey RA, Myers SC. 2000. Principles of Corporate Finance (6th edn). McGraw-Hill: Boston, MA. 
Chi, Tailan. (2012) Venture Capitalists' Decision to Withdraw: The Role of Portfolio Configuration From a Real Options Lens. Strategic Management Journal. Publisher's Official Version: http://papers.ssrn.com/sol3/papers.cfm?abstract_id=2036399 Open Access Version: http://kuscholarworks.ku.edu/dspace/

Brennan MJ, Schwartz ES. 1985. Evaluating natural resource investments. Journal of Business 58(2): 135-157.

Cameron AC, Trivedi PK. 2005. Microeconometrics: Methods and Applications. Cambridge University Press: New York.

Chi T, Nystrom PC. 1995. Decision dilemmas facing managers: recognizing the value of learning while making sequential decisions. Omega-International Journal of Management Science 23(3): 303-312.

Cochrane JH. 2005. The risk and return of venture capital. Journal of Financial Economics 75(1): 3-52.

Cossin D, Leleux B, Saliasi E. 2002. Understanding the economic value of legal covenants in investment contracts: a real options approach to venture equity contracts. FAME research paper 63. Available at http://ssrn.com/abstract=375560 (accessed 12 November 2011).

Cumming DJ. 2006. The determinants of venture capital portfolio size: empirical evidence. Journal of Business 79(3): 1083-1126.

Cumming D, Fleming G, Schwienbacher A. 2005. Liquidity risk and venture capital finance. Financial Management 34(4): 77-105.

Dixit AK. 1989. Entry and exit decisions under uncertainty. Journal of Political Economy 97(3): 620-638.

Dixit AK. 1992. Investment and hysteresis. Journal of Economic Perspectives 6(1): 107-132.

Dixit AK, Pindyck RS. 1994. Investment Under Uncertainty. Princeton University Press: Princeton, NJ.

Dixit AK, Pindyck RS. 2000. Expandability, reversibility, and optimal capacity choice. In Project Flexibility, Agency, and Competition: New Developments in the Theory and Application of Real Options, Brennan MJ, Trigeorgis LG (eds). Oxford University Press: New York.

Fama EF, French KR. 1993. Common risk-factors in the returns on stocks and bonds. Journal of Financial Economics 33(1): 3-56.

Fenn GW, Liang N, Prowse S. 1997. The private equity market: an overview. Financial Markets and Instruments 6(4): 1-106.

Folta TB. 1998. Governance and uncertainty: the trade-off between administrative control and commitment. Strategic Management Journal 19(11): 1007-1028. 
Chi, Tailan. (2012) Venture Capitalists' Decision to Withdraw: The Role of Portfolio Configuration From a Real Options Lens. Strategic Management Journal. Publisher's Official Version: http://papers.ssrn.com/sol3/papers.cfm?abstract_id=2036399 Open Access Version: http://kuscholarworks.ku.edu/dspace/

Folta TB. 2005. Are real options 'real?’ In Research Methodology in Strategy and Management, Ketchen DJ, Bergh DD (eds). Elsevier JAI: Boston, MA.

Folta TB, Johnson DR, O'Brien J. 2006. Uncertainty, irreversibility, and the likelihood of entry: an empirical assessment of the option to defer. Journal of Economic Behavior \& Organization 61(3): 432-452.

Folta TB, O'Brien JP. 2004. Entry in the presence of dueling options. Strategic Management Journal 25(2): 121-138.

Gimeno J, Folta TB, Cooper AC, Woo CY. 1997. Survival of the fittest? Entrepreneurial human capital and the persistence of underperforming firms. Administrative Science Quarterly 42(4): 750-783.

Girotra K, Terwiesch C, Ulrich KT. 2007. Valuing R\&D projects in a portfolio: evidence from the pharmaceutical industry. Management Science 53(9): 1452-1466.

Global Insight, Inc. 2007. Venture impact: the economic importance of venture capital backed companies to the U.S. economy. IHS Inc. report: Englewood, CO.

Gompers P. 1995. Optimal investment, monitoring, and the staging of venture capital. Journal of Finance 50(5): 1461-1489.

Gompers P, Kovner A, Lerner J, Scharfstein D. 2008. Venture capital investment cycles: the impact of public markets. Journal of Financial Economics 87(1): 1-23.

Gompers P, Lerner J. 2000. Money chasing deals? The impact of fund inflows on private equity valuations. Journal of Financial Economics 55(2): 281-325.

Gompers P, Lerner J. 2002. The Venture Capital Cycle. MIT Press: Cambridge, MA.

Guiso L, Parigi G. 1999. Investment and demand uncertainty. Quarterly Journal of Economics 114(1): 185-227.

Gulati R, Higgins MC. 2003. Which ties matter when? The contingent effects of interorganizational partnerships on IPO success. Strategic Management Journal 24(2): 127-144.

Guler I. 2007. Throwing good money after bad? Political and institutional influences on sequential decision making in the venture capital industry. Administrative science quarterly 52(2): 248-285.

Henley A, Carruth A, Dickerson A. 2003. Industry-wide versus firm-specific uncertainty and investment: British company panel data evidence. Economics Letters 78(1): 87-92. 
Chi, Tailan. (2012) Venture Capitalists' Decision to Withdraw: The Role of Portfolio Configuration From a Real Options Lens. Strategic Management Journal. Publisher's Official Version: http://papers.ssrn.com/sol3/papers.cfm?abstract_id=2036399 Open Access Version: http://kuscholarworks.ku.edu/dspace/

Hochberg YV, Ljungqvist A, Lu Y. 2007. Whom you know matters: venture capital networks and investment performance. Journal of Finance 62(1): 251-301.

Hurry D, Miller AT, Bowman EH. 1992. Calls on high-technology: Japanese exploration of venture capital investments in the United States. Strategic Management Journal 13(2): 85-101.

Jacquemin AP, Berry CH. 1979. Entropy measure of diversification and corporate growth. Journal of Industrial Economics 27: 359-369.

Johnson H. 1987. Options on the maximum or the minimum of several assets. Journal of Financial and Quantitative Analysis 22(3): 277-283.

Kaplan SN, Schoar A. 2005. Private equity performance: returns, persistence, and capital flows. Journal of Finance 60(4): 1791-1823.

Knill A. 2009. Should venture capitalists put all their eggs in one basket? Diversification versus pure-play strategies in venture capital. Financial Management 38(3): 441-486.

Kogut B. 1991. Joint ventures and the option to expand and acquire. Management Science 37(1): 19-33.

Kortum S, Lerner J. 2000. Assessing the contribution of venture capital to innovation. RAND Journal of Economics 31(4): 674-692.

Kulatilaka N. 1995. Operating flexibilities in capital budgeting: substitutability and complementarity in real options. In Real Options in Capital Investment: Models, Strategies, and Applications, Trigeorgis L (ed). Praeger: Westport, CT.

Kumar MVS. 2005. The value from acquiring and divesting a joint venture: a real options approach. Strategic Management Journal 26(4): 321-331.

Li Y. 2008. Duration analysis of venture capital staging: a real options perspective. Journal of Business Venturing 23(5): 497-512.

Li Y, James B, Madhavan R, Mahoney JT. 2007. Real options: taking stock and looking ahead. Advances in Strategic Management 24: 31-66.

Li Y, Mahoney JT. 2011. When are venture capital projects initiated? Journal of Business Venturing 26(2): 239-254.

Mahoney JT. 2005. Economic Foundations of Strategy. SAGE Publications: Thousand Oaks, CA. Margrabe W. 1978. The value of an option to exchange one asset for another. Journal of Finance 33: 177-186. 
Chi, Tailan. (2012) Venture Capitalists' Decision to Withdraw: The Role of Portfolio Configuration From a Real Options Lens. Strategic Management Journal. Publisher's Official Version: http://papers.ssrn.com/sol3/papers.cfm?abstract_id=2036399 Open Access Version: http://kuscholarworks.ku.edu/dspace/

Markowitz H. 1959. Portfolio Selection: Efficient Diversification of Investments. Wiley: New York.

McDonald RL, Siegel D. 1986. The value of waiting to invest. Quarterly Journal of Economics 101(4): 707-727.

McGrath RG. 1997. A real options logic for initiating technology positioning investments. Academy of Management Review 22(4): 974-996.

McGrath RG. 1999. Falling forward: real options reasoning and entrepreneurial failure. Academy of Management Review 24(1): 13-30.

McGrath RG, MacMillan IC. 2000. Assessing technology projects using real options reasoning. Research-Technology Management 43(4): 35-49.

McGrath RG, Nerkar A. 2004. Real options reasoning and a new look the R\&D investment strategies of pharmaceutical firms. Strategic Management Journal 25(1): 1-21.

Moel A, Tufano P. 2002. When are real options exercised? An empirical study of mine closings. Review of Financial Studies 15(1): 35-64.

National Venture Capital Association. 2008. The Venture Capital Industry-An Overview. NVCA: Arlington, VA.

Norton E, Tenenbaum BH. 1993. Specialization versus diversification as a venture capitalinvestment strategy. Journal of Business Venturing 8(5): 431-442.

O'Brien J, Folta T. 2009. Sunk costs, uncertainty and market exit: a real options perspective. Industrial and Corporate Change 18(5): 807-833.

Oriani R, Sobrero M. 2008. Uncertainty and the market valuation of R\&D within a real options logic. Strategic Management Journal 29(4): 343-361.

Palepu K. 1985. Diversification strategy, profit performance and the entropy measure. Strategic Management Journal 6(3): 239-255.

Reuer JJ, Tong TW (eds). 2007. Real Options Theory Elsevier: Greenwich, CT.

Ritter JR. 1984. The hot issue market of 1980. Journal of Business 57(2): 215-240.

Sahlman WA. 1990. The structure and governance of venture-capital organizations. Journal of Financial Economics 27(2): 473-521.

Shleifer A, Vishny RW. 1992. Liquidation values and debt capacity: a market equilibrium approach. Journal of Finance 47(4): 1343-1366. 
Sorenson O, Stuart TE. 2001. Syndication networks and the spatial distribution of venture capital investments. American journal of sociology 106(6): 1546-1588.

Stulz RM. 1982. Options on the minimum or the maximum of two risky assets: analysis and applications. Journal of Financial Economics 10: 161-185.

Trigeorgis L. 1988. A conceptual options framework for capital budgeting. Advances in Futures and Options Research 3: 145-167.

Trigeorgis L. 1993. The nature of option interactions and the valuation of investments with multiple real options. Journal of Financial And Quantitative Analysis 28(1): 1-20.

Trigeorgis L. 1996. Real Options: Managerial Flexibility and Strategy in Resource Allocation. MIT Press: Cambridge, MA.

Trigeorgis L. 2005. Making use of real options simple: an overview and applications in flexible/modular decision making. Engineering Economist 50(1): 25-53.

Vassolo RS, Anand J, Folta TB. 2004. Non-additivity in portfolios of exploration activities: a real options-based analysis of equity alliances in biotechnology. Strategic Management Journal 25(11): 1045-1061. 


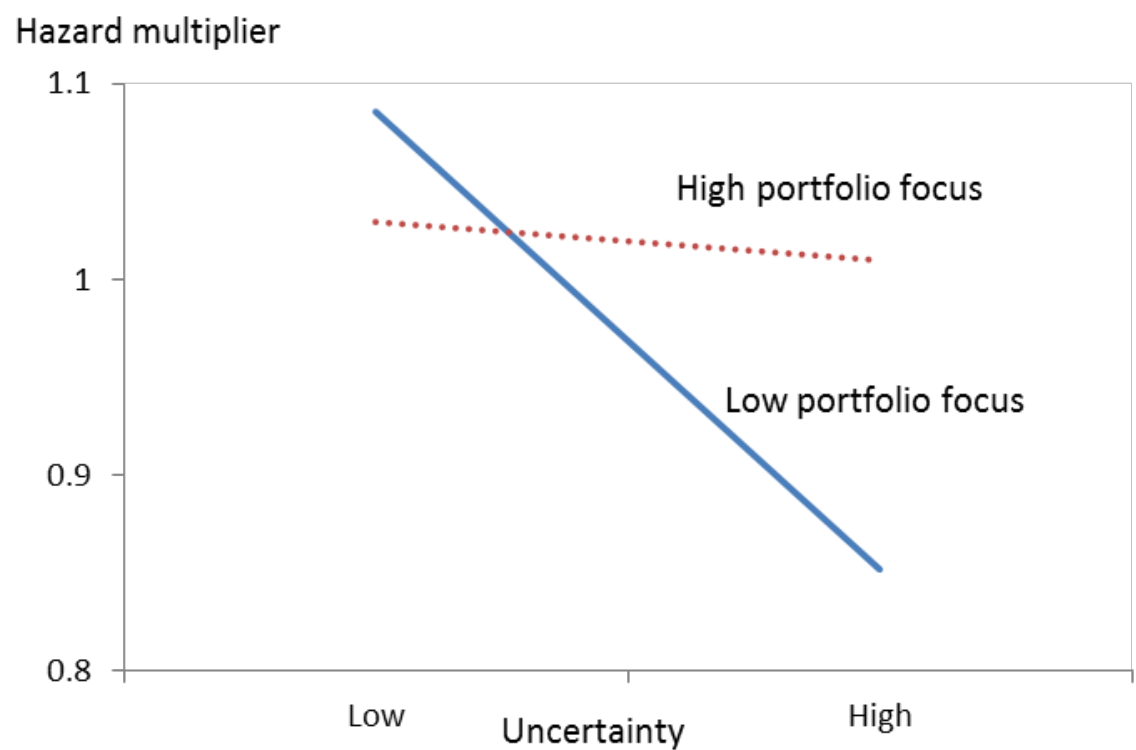

1a. Portfolio focus, uncertainty and propensity to withdraw

Hazard multiplier

1.1

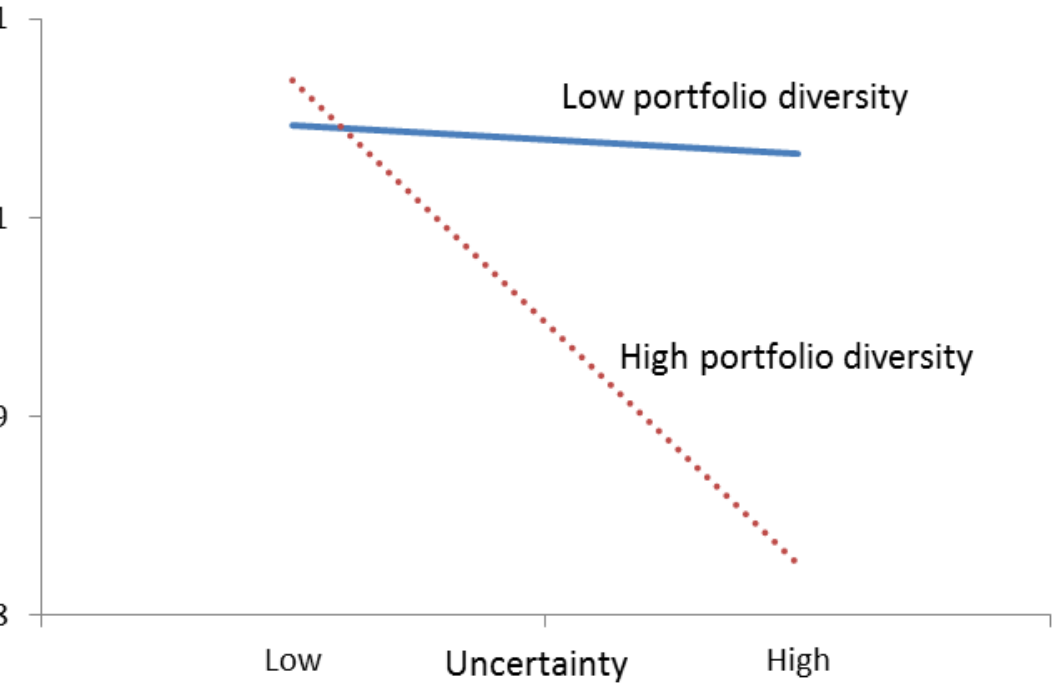

1b. Portfolio diversity, uncertainty and propensity to withdraw

\section{Figure 1. Interaction effects of uncertainty and portfolio configuration on propensity to} withdraw

Note: The figures are based on point estimates in Model 5 of Table 3. The vertical axis represents the hazard multiplier, the horizontal axis the level of uncertainty. 'Low' denotes a variable's value at the 20th percentile; 'High' denotes a variable's value at the 80th percentile. The value of other variables is held at the mean level. 
Chi, Tailan. (2012) Venture Capitalists' Decision to Withdraw: The Role of Portfolio Configuration From a Real Options Lens. Strategic Management Journal. Publisher's Official Version: http://papers.ssrn.com/sol3/papers.cfm?abstract id=2036399 Open Access Version: http://kuscholarworks.ku.edu/dspace/

\section{Table 1. Variable definitions}

\begin{tabular}{l}
\hline Variable \\
\hline Dependent variable: \\
Propensity to withdraw
\end{tabular}

Description

Propensity to withdraw

The hazard that a VC withdraws its investment in a venture in the current round conditional on the fact that the VC has invested in the previous round. For estimation, we calculate the duration of time from one round to the next round or exit in days.

\section{Independent variables: \\ Uncertainty (industry volatility)}

\section{Portfolio focus}

Portfolio diversity

Venture-related controls:

\section{Stage of development}

Venture industry growth
Annualized squared standard error (i.e., 'root mean squared error') from the regression of monthly excess market returns in an industry on the three Fama-French factors (Fama and French, 1993). We specify the estimation model as follows: $R_{t}-R F_{t}=a+b^{*} M K T R F_{t}+s^{*} S M B_{t}+h * H M L_{t}+e_{t} . R_{t}$ is the return on the stock portfolio in an industry, $R F_{t}$ the risk-free return rate, $R_{t}-R F_{t}$ the excess return on the stock portfolio, $M K T R F_{t}$ the excess market return over the risk-free return rate where the market return is the value weighted return on all stocks, $S M B_{t}$ the difference between small firm return and big firm return, $H M L_{t}$ the difference between high book-to-market equity return and low book-to-market equity return. The average adjusted R-square for all the regressions is 0.58 , suggesting that the model captures a significant fraction of the variation in stock returns (Fama and French, 1993). Our uncertainty measure is industry specific and time varying. See also Brav and Gompers (1997), Folta, Johnson, and O'Brien (2006), and Li and Mahoney (2011). Data are collected from CRSP.

The weighted average of the shares of each project the VC has funded in a given industry in a five-year period (current year included), the weight for each project being the logarithm of the inverse of its share in the portfolio (Jacquemin and Berry, 1979; Palepu, 1985). This measure is time varying, VC specific, and venture industry specific. This measure takes into account the number of industries in which the VC operates and the relative importance of each of the industries in the VC's portfolio. Results hold for measures based on a threeor seven-year period. Data are collected from VentureXpert.

The weighted average of the shares of the industries in which the VC has invested in a five-year period (current year included), the weight for each industry being the logarithm of the inverse of its share in the portfolio. This measure is VC specific and time varying. Results hold for measures based on a three- or seven-year period. Data are collected from VentureXpert.

An ordinal measure with start-up stage $=1$, early stage $=2$, expansion stage $=3$, later stage $=4$, where the stages are defined by the National Venture Capital Association. Data are collected from VentureXpert.

The difference between the actual returns and the forecast from the Fama-French model estimation of industry 
Chi, Tailan. (2012) Venture Capitalists' Decision to Withdraw: The Role of Portfolio Configuration From a Real Options Lens. Strategic Management Journal. Publisher's Official Version: http://papers.ssrn.com/sol3/papers.cfm?abstract_id=2036399 Open Access Version: http://kuscholarworks.ku.edu/dspace/

returns. See Kogut (1991) for a similar measure.

VC-related controls:

VC syndicate size

VC fund age

VC's early-stage investment experience

Dyadic-level controls:

Geographic proximity

Rounds

VC's total investment in venture

Market-level controls:

IPO market condition

\section{Capital committed to venture capital industry \\ Venture industry dummies \\ Year dummies}

A time-varying count of the number of VCs that participated in the prior financing round for a venture. The difference between the focal round year and the fund vintage year in VentureXpert.

The proportion of the start-up- and early-stage ventures among all the ventures that the VC has funded in the last five years prior to the focal deal.

\section{Dummy variable that takes the value ' 1 ' if the VC operates in the same state as the venture.}

The total number of rounds of financing that the VC has provided for the venture by the time of current financing.

The VC's cumulative disbursement in the venture, calculated as the log of the sum of the dollar amounts the VC has invested in the venture in all prior rounds before the focal round (in thousand US\$).

The log of the number of IPOs in the U.S. market in the year of investment. Data are collected from SDC's Global New Issues database.

The total capital committed to the whole venture capital industry in the year of investment (log of million US\$), defined as the amount of capital that limited partners pledged to provide for venture capital funds (Gompers, 1995).

Set of mutually exclusive dummy variables that take the value ' 1 ' if the venture operates in one of the FamaFrench industries.

Set of dummy variables each of which takes the value ' 1 ' if the withdrawal took place in 1980, 1981, ..., 2009 (respectively). 
Chi, Tailan. (2012) Venture Capitalists' Decision to Withdraw: The Role of Portfolio Configuration From a Real Options Lens. Strategic Management Journal. Publisher's Official Version: http://papers.ssrn.com/sol3/papers.cfm?abstract id=2036399 Open Access Version: http://kuscholarworks.ku.edu/dspace/

\section{Table 2. Descriptive statistics and correlations}

\begin{tabular}{|c|c|c|c|c|c|c|c|c|c|c|c|c|c|c|c|c|}
\hline No. & Variables & 1 & 2 & 3 & 4 & 5 & 6 & 7 & 8 & 9 & 10 & 11 & 12 & 13 & 14 & 15 \\
\hline 1 & Stage of development & 1.00 & & & & & & & & & & & & & & \\
\hline 2 & Venture industry growth & -0.03 & 1.00 & & & & & & & & & & & & & \\
\hline 3 & VC syndicate size & 0.08 & 0.04 & 1.00 & & & & & & & & & & & & \\
\hline 4 & VC fund age & 0.02 & -0.02 & -0.02 & 1.00 & & & & & & & & & & & \\
\hline 5 & $\begin{array}{l}\text { VC's early-stage investment } \\
\text { experience }\end{array}$ & -0.17 & 0.06 & 0.01 & 0.03 & 1.00 & & & & & & & & & & \\
\hline 6 & Geographic proximity & -0.02 & -0.01 & -0.04 & -0.10 & 0.09 & 1.00 & & & & & & & & & \\
\hline 7 & Rounds & 0.24 & -0.02 & -0.10 & 0.07 & 0.10 & 0.05 & 1.00 & & & & & & & & \\
\hline 8 & VC's total investment in venture & 0.33 & -0.08 & -0.00 & 0.01 & -0.19 & 0.01 & 0.22 & 1.00 & & & & & & & \\
\hline 9 & IPO market conditions & -0.03 & 0.07 & -0.03 & 0.00 & 0.03 & -0.01 & -0.04 & -0.02 & 1.00 & & & & & & \\
\hline 10 & Capital committed to VC industry & 0.17 & -0.15 & -0.13 & 0.09 & -0.28 & 0.06 & 0.03 & 0.42 & -0.29 & 1.00 & & & & & \\
\hline 11 & Uncertainty & 0.00 & -0.06 & -0.13 & 0.01 & -0.09 & 0.04 & -0.04 & 0.12 & 0.04 & 0.25 & 1.00 & & & & \\
\hline 12 & Portfolio focus & 0.03 & -0.04 & -0.03 & 0.31 & 0.07 & -0.03 & 0.05 & 0.20 & 0.01 & 0.26 & 0.41 & 1.00 & & & \\
\hline 13 & Portfolio diversity & -0.04 & 0.05 & -0.01 & 0.19 & 0.25 & -0.09 & 0.15 & -0.12 & -0.00 & -0.36 & -0.19 & 0.13 & 1.00 & & \\
\hline 14 & $\begin{array}{l}\text { Uncertainty } \mathrm{x} \\
\text { portfolio focus* }\end{array}$ & -0.01 & -0.02 & -0.09 & 0.18 & -0.02 & -0.03 & -0.02 & 0.05 & 0.02 & 0.13 & 0.18 & 0.33 & 0.00 & 1.00 & \\
\hline 15 & $\begin{array}{l}\text { Uncertainty x } \\
\text { portfolio diversity* }\end{array}$ & 0.02 & 0.02 & 0.02 & 0.07 & 0.01 & -0.01 & 0.00 & -0.02 & 0.01 & -0.01 & -0.01 & 0.02 & -0.02 & 0.23 & 1.00 \\
\hline & Mean & 2.95 & -0.13 & 5.61 & 7.18 & 0.18 & 0.38 & 1.56 & 6.69 & 6.74 & 9.03 & 5.77 & 1.80 & 1.38 & 1.7 & -0.37 \\
\hline & S.D. & 0.94 & 1.49 & 4.30 & 8.12 & 0.18 & 0.49 & 1.81 & 2.54 & 0.35 & 1.20 & 3.06 & 1.38 & 0.65 & 3.97 & 1.89 \\
\hline & VIF & 1.20 & 1.03 & 1.08 & 1.19 & 1.20 & 1.04 & 1.18 & 1.44 & 1.16 & 1.85 & 1.37 & 1.67 & 1.40 & 1.21 & 1.07 \\
\hline
\end{tabular}

$\mathrm{N}=139,042$. Those with “*” are the interaction terms of centered variables. Correlations with absolute values larger than 0.01 are significant at $\mathrm{p}<0.01$. 
Chi, Tailan. (2012) Venture Capitalists' Decision to Withdraw: The Role of Portfolio Configuration From a Real Options Lens. Strategic Management Journal. Publisher's Official Version: http://papers.ssrn.com/sol3/papers.cfm?abstract_id=2036399 Open Access Version: http://kuscholarworks.ku.edu/dspace/

Table 3. Results for the propensity to withdraw from Cox models

\begin{tabular}{|c|c|c|c|c|c|c|}
\hline \multirow{2}{*}{ Stage of development } & & 1 & 2 & 3 & 4 & 5 \\
\hline & & $\begin{array}{c}-0.236 * * * \\
(0.008)\end{array}$ & $\begin{array}{c}-0.235^{* * *} \\
(0.008)\end{array}$ & $\begin{array}{c}-0.235^{* * * *} \\
(0.008)\end{array}$ & $\begin{array}{c}-0.234 * * * \\
(0.008)\end{array}$ & $\begin{array}{c}-0.232 * * * \\
(0.008)\end{array}$ \\
\hline Venture industry growth & & $\begin{array}{l}-0.011^{*} \\
(0.005)\end{array}$ & $\begin{array}{l}-0.011^{*} \\
(0.005)\end{array}$ & $\begin{array}{l}-0.011^{*} \\
(0.005)\end{array}$ & $\begin{array}{l}-0.010^{*} \\
(0.005)\end{array}$ & $\begin{array}{l}-0.010^{*} \\
(0.005)\end{array}$ \\
\hline VC syndicate size & & $\begin{array}{c}0.043 * * * \\
(0.001)\end{array}$ & $\begin{array}{c}0.043 * * * \\
(0.001)\end{array}$ & $\begin{array}{c}0.043^{* * *} \\
(0.001)\end{array}$ & $\begin{array}{c}0.043^{* * *} \\
(0.001)\end{array}$ & $\begin{array}{c}0.043^{* * *} \\
(0.001)\end{array}$ \\
\hline VC fund age & & $\begin{array}{c}0.003^{* * *} \\
(0.001)\end{array}$ & $\begin{array}{c}0.004 * * * \\
(0.001)\end{array}$ & $\begin{array}{c}0.003^{* * *} \\
(0.001)\end{array}$ & $\begin{array}{c}0.004^{* * *} \\
(0.001)\end{array}$ & $\begin{array}{c}0.003^{* * *} \\
(0.001)\end{array}$ \\
\hline \multirow[t]{2}{*}{$\begin{array}{l}\text { VC's early-stage investment } \\
\text { experience }\end{array}$} & & $-0.593 * * *$ & $-0.587 * * *$ & $-0.581 * * *$ & $-0.593 * * *$ & $-0.584 * * *$ \\
\hline & & $(0.046)$ & $(0.046)$ & $(0.045)$ & $(0.046)$ & $(0.046)$ \\
\hline Geographic proximity & & $\begin{array}{c}-0.172 * * * \\
(0.014)\end{array}$ & $\begin{array}{c}-0.172 * * * \\
(0.014)\end{array}$ & $\begin{array}{c}-0.172 * * * \\
(0.014)\end{array}$ & $\begin{array}{c}-0.172 * * * \\
(0.014)\end{array}$ & $\begin{array}{c}-0.171 * * * \\
(0.014)\end{array}$ \\
\hline Rounds & & $\begin{array}{c}0.091^{* * *} \\
(0.005)\end{array}$ & $\begin{array}{c}0.091^{* * *} \\
(0.005)\end{array}$ & $\begin{array}{c}0.092^{* * *} \\
(0.005)\end{array}$ & $\begin{array}{c}0.091^{* * *} \\
(0.005)\end{array}$ & $\begin{array}{c}0.091^{* * *} \\
(0.005)\end{array}$ \\
\hline \multirow[t]{2}{*}{$\begin{array}{l}\text { VC's total investment in } \\
\text { venture }\end{array}$} & & $-0.108 * * *$ & $-0.108 * * *$ & $-0.108 * * *$ & $-0.109 * * *$ & $-0.109 * * *$ \\
\hline & & $(0.005)$ & $(0.005)$ & (0.005) & $(0.005)$ & $(0.005)$ \\
\hline IPO market conditions & & $\begin{array}{l}-0.065 \\
(0.508)\end{array}$ & $\begin{array}{l}-0.008 \\
(0.508)\end{array}$ & $\begin{array}{l}-0.027 \\
(0.508)\end{array}$ & $\begin{array}{l}-0.016 \\
(0.510)\end{array}$ & $\begin{array}{l}-0.028 \\
(0.510)\end{array}$ \\
\hline \multirow[t]{2}{*}{$\begin{array}{l}\text { Capital committed to VC } \\
\text { industry }\end{array}$} & & 0.041 & 0.054 & 0.049 & 0.051 & 0.047 \\
\hline & & $(0.104)$ & $(0.104)$ & $(0.104)$ & $(0.104)$ & $(0.104)$ \\
\hline Portfolio focus & & $\begin{array}{c}0.033^{* * *} \\
(0.006)\end{array}$ & $\begin{array}{c}0.027 * * * \\
(0.006)\end{array}$ & $\begin{array}{c}0.019 * * \\
(0.007)\end{array}$ & $\begin{array}{c}0.034^{* * *} \\
(0.007)\end{array}$ & $\begin{array}{c}0.018 * * \\
(0.007)\end{array}$ \\
\hline Portfolio diversity & & $\begin{array}{c}-0.065^{* * * *} \\
(0.012)\end{array}$ & $\begin{array}{c}-0.060 * * * \\
(0.012)\end{array}$ & $\begin{array}{c}-0.056^{* * * *} \\
(0.012)\end{array}$ & $\begin{array}{c}-0.076^{* * * *} \\
(0.012)\end{array}$ & $\begin{array}{c}-0.077 * * * \\
(0.012)\end{array}$ \\
\hline Uncertainty & Baseline & & $\begin{array}{c}-0.088 * * * \\
(0.017)\end{array}$ & $\begin{array}{c}-0.079 * * * \\
(0.017)\end{array}$ & $\begin{array}{l}-0.036^{*} \\
(0.018)\end{array}$ & $\begin{array}{l}-0.020 \\
(0.021)\end{array}$ \\
\hline Uncertainty x portfolio focus & H1 & & & $\begin{array}{c}0.006 * * * \\
(0.002)\end{array}$ & & $\begin{array}{c}0.015^{* * *} \\
(0.002)\end{array}$ \\
\hline $\begin{array}{l}\text { Uncertainty x portfolio } \\
\text { diversity }\end{array}$ & $\mathbf{H} 2$ & & & & $-0.025 * * *$ & $-0.036 * * *$ \\
\hline $\begin{array}{l}\text { Venture industry dummies } \\
\text { Year dummies }\end{array}$ & & $\begin{array}{l}\text { Included } \\
\text { Included }\end{array}$ & $\begin{array}{l}\text { Included } \\
\text { Included }\end{array}$ & $\begin{array}{l}\text { Included } \\
\text { Included }\end{array}$ & $\begin{array}{l}(0.004) \\
\text { Included } \\
\text { Included }\end{array}$ & $\begin{array}{l}(0.004) \\
\text { Included } \\
\text { Included }\end{array}$ \\
\hline Observations & & 139,042 & 139,042 & 139,042 & 139,042 & 139,042 \\
\hline No. of VC-venture pairs & & 52,891 & 52,891 & 52,891 & 52,891 & 52,891 \\
\hline No. of withdrawals & & 28,230 & 28,230 & 28,230 & 28,230 & 28,230 \\
\hline Log likelihood & & $-42,309$ & $-42,296$ & $-42,289$ & $-42,266$ & $-42,223$ \\
\hline Wald chi square & & 6,791 & 6,792 & 6,904 & 6,792 & 7,052 \\
\hline AIC & & 84,781 & 84,758 & 84,746 & 84,699 & 84,619 \\
\hline
\end{tabular}

Note: Variables in the regressions are either centered variables or the interaction terms of centered variables. Robust standard errors appear in parentheses. ${ }^{* * *} \mathrm{p}<0.001$, ** $\mathrm{p}<0.01,{ }^{*} \mathrm{p}<0.05,+\mathrm{p}<0.10$. 